\title{
Impact of phytopathogens on seed quality of tropical grasses in integrated systems
}

\author{
Anne Caroline Dallabrida Avelino ${ }^{1}$, Dayana Aparecida de Faria ${ }^{1}$, Wender Mateus Peixoto ${ }^{1}$, Elisangela \\ Clarete Camili ${ }^{1}$, Virgínia Helena de Azevedo ${ }^{1}$, Arthur Behling Neto ${ }^{2}$, Cárita Rodrigues de Aquino Arantes ${ }^{1}$, \\ Giovani Oliveira de Arieira ${ }^{1+}$, Joadil Gonçalves de Abreu $^{1}$
}

\author{
${ }^{1}$ Department of Agronomy and Zootechny, Federal University of Mato Grosso, Cuiabá, Mato Grosso, Brazil \\ ${ }^{2}$ Institute of Agrarian and Technological Sciences, Federal University of Mato Grosso, Sinop, Mato Grosso, Brazil
}

\section{*Corresponding author: annedallabrida@hotmail.com}

\begin{abstract}
This study aimed to identify the main fungal and phytonematode genotypes associated with the main tropical forage seeds used in integrated systems and to distinguish seeds with high physiological and sanitary quality, for which two experiments were conducted. In year 1 (2017/18 crop year), the first experiment (experiment 1) was conducted with seeds produced in the 2017/18 crop year, in a randomized open design with four configurations and four replications. In year 2 (2018/19 crop year), the study (experiment 2) was replicated with the experimental conditions of the first experiment (randomized automatic design, with four sessions and four replications), but using samples from the 2018/19 crop year. The seeds were produced in the 2017/18 and 2018/19 crop years, with the same origin, and were purchased within commercial packages. The treatments of experiments 1 and 2 were the same and consisted of seeds of Brachiaria ruziziensis and the Brachiaria brizantha cultivars Marandu, Xaraés, and BRS Piatã. The same variables were evaluated for each experiment: water content, physical purity, viability, germination rate index, first germination count, germination percentage, crop value, dormancy, accelerated aging, and incidence of fungi and phytonematodes. Cladosporium sp., Fusarium sp., Rhizoctonia sp., Meloidogyne sp., Filenchus sp., Aphelenchus sp., Aphelencoides sp., and Rotylenchulus sp. are the main phytopathogens associated with seeds of the main tropical forage species used in integrated systems. The seeds of $B$. ruziziensis present high physiological quality, whereas the seeds of the $B$. brizantha cultivar Xaraés grass present high sanitary quality.
\end{abstract}

Keywords: Fungal plant pathogens, germination, tropical pastures.

Introduction

Over the years, there has been a need to maximize the food outcome in response to intensified livestock production while ruling out the need to open new agricultural areas. However, most of the existing grazing areas exhibit some degree of degradation (Souza et al. 2017). In this regard, sustainable crop models have been developed, such as croplivestock integration (CLI), allowing the recovery of degraded areas, the intensification of pasture production (and the production of forage seeds), and, consequently, the increase in the content of animal protein (Macedo, 2009; Balbino et al., 2011; Leonel, 2011; Vilela et al., 2011; Cordeiro et al., 2015).

Although economically expressive, the forage seed production system is threatened by the presence of pathogens. Due to the absence of sanitary standards in Brazilian trade regulations, seeds have acted as an efficient mechanism of introduction and dispersion of pathogens that may affect several moments, from the stage of stand establishment to harvest (Vechiato and Aparecido, 2008).

Among the pathogens associated with tropical forage seeds of the genus Brachiaria syn. Urochloa, fungi and phytonematodes are highlighted. Phytopathogenic fungi are among the factors that most reduce the productivity of agricultural crops (Godoy et al. 2014). Furthermore, integrated systems can favor the increase of the population of phytonematodes since they provide lower surface temperatures (Freire et al. 2018). When present in seeds, fungi may cause reduced germination, decreasing their quality and commercial value (Lasca et al., 2004). Besides, it is believed that phytonematodes can have a significant impact on dry matter production and the persistence of the forage in the field (Favoreto, 2004).

In order to define new alternatives and management strategies for the eradication of fungi and phytonematodes from the agricultural fields of integrated production systems, it is important to identify and analyze the population of these phytopathogens in the seeds of the main forage species grown in integrated systems (sanitary quality) and to assess the interference of these phytopathogens on the physiological quality of these seeds (Calgaro Junior, 2019). Based on this, this study aimed to identify the main genera of fungi and phytonematodes associated with the main tropical forage seeds employed in integrated systems, as well as to distinguish seeds with high physiological and sanitary quality. 


\section{Results}

\section{Experiment 1 - Year 1; 2017/2018 crop year}

In experiment 1, using seeds produced in the 2017/2018 crop year, there was an effect of the treatment on the following variables: water content, purity, first germination count, germination percentage, germination rate index, viability, dormancy, crop value based on germination, crop value based on viability, and germination of aged seeds of Brachiaria $(p<0.05)$. B. ruziziensis presented the lowest water content $(10.21 \%)$ among the studied species/cultivars (Table 1).

It was observed that none of the seed lots reached the minimum purity index of $80 \%$ required for the commercialization of seeds of Brachiaria sp. (Brasil, 2008). Besides, considering that the minimum germination standard or viability to commercialize the seeds of Brachiaria sp. should be $60 \%$ (Brasil, 2008; Brasil, 2010), it was verified that the seed lot of the $B$. brizantha cultivar Xaraés was below the germination standard, whereas the seed lot of the $B$. brizantha cultivar Marandu was not within either the germination or viability standards for commercialization. The seeds of the $B$. brizantha cultivar Marandu presented the lowest viability percentage results. It was also verified that the seeds of $B$. ruziziensis and the $B$. brizantha cultivar BRS Piatã presented higher results of the first germination count, which is indicative of greater vigor. The germination percentage was higher in the seeds of $B$. ruziziensis (Table 1 ).

The sanitary analysis of the Brachiaria seeds that were not subjected to disinfection revealed the incidence of the fungi Alternaria sp., Aspergillus sp., Cladosporium sp., Colletotrichum sp., Curvularia sp. Fusarium sp., Penicillium sp., Rhizoctonia sp., and Rhizopus sp. When the previous disinfection process was performed, a lower incidence of all the above-mentioned fungi was verified, except for Cladosporium sp. and Rhizoctonia sp., which presented an increase in frequency and Colletotrichum sp., Curvularia sp. and Penicillium sp., which were not detected (Table 2).

After the disinfection process, it is estimated that with the reduction in the infestation by Fusarium sp., the development of the fungi Cladosporium sp. and Rhizoctonia sp. may have been favored. Regarding the genus Cladosporium sp., the non-disinfected seeds of the $B$. brizantha cultivar BRS Piatã presented a high incidence rate. However, considering the seeds after the disinfection process, there was no effect of the treatment on the incidence of Cladosporium sp. (Table 2).

In the phytonematode analysis, the presence of eggs and free-living phytonematodes (non-parasites) was observed in all seed lots analyzed by the method without incubation. There was no treatment effect on egg incidence, and there was a high incidence of free-living phytonematodes in the seeds of $B$. ruziziensis (Table 3 ).

After the incubation period, the incidence of eggs and freeliving phytonematodes was verified, with a predominance of incidence in the seeds of $B$. ruziziensis. Furthermore, the incidence of the phytopathogenic fungi Meloidogyne sp., Aphelenchus sp., and Filenchus sp. was observed in all the seeds, except for the $B$. brizantha cultivar Xaraés. However, there was no treatment effect on the incidence of phytopathogenic fungi for the studied species/cultivars (Table 3).
Experiment 2 - Year 2; 2018/2019 crop year

In experiment 2, using the seeds of the 2018/2019 crop year, there was also a treatment effect on all variables, except for the water content and the crop value based on viability $(p<0.05)$. The mean water content value was $9.58 \%$. All seed lots reached the minimum purity index (80\%) required for seed commercialization. Moreover, none of the lots reached the minimum germination index $(60 \%)$, and the seed lot of the $B$. brizantha cultivar Xaraés was the only one below the viability standards $(60 \%)$ for commercialization (Table 1 ). When calculating the crop value based on germination, it was observed that only the seed lots of $B$. ruziziensis and the B. brizantha cultivar BRS Piatã reached a commercialization minimum (48\%).

Besides the seeds of the $B$. brizantha cultivar Marandu, the seeds of the $B$. brizantha cultivar Xaraés also showed a lower viability percentage. This suggests that the Marandu and Xaraés cultivars present high levels of non-viable (dead) seeds in the commercialized lots. The seeds of $B$. ruziziensis presented the highest germination percentage in the first count. The germination percentage was higher in the seeds of $B$. ruziziensis and in the B. brizantha cultivar BRS Piatã (Table 1).

The sanitary analysis of the Brachiaria seeds without disinfection revealed the incidence of the fungi Aspergillus sp., Cladosporium sp., Colletotrichum sp., Fusarium sp., Penicillium sp., Rhizoctonia sp., and Rhizopus sp. A lower incidence of all fungi was verified, as well as the absence of the fungus Colletotrichum sp. There was no treatment effect on the incidence of Cladosporium sp. in the non-disinfected seeds. After the disinfection process, the seeds of $B$. ruziziensis and the $B$. brizantha cultivar BRS Piatã showed a higher incidence of this phytopathogen. $A$ reduction trend was observed for the incidence of all major fungi (Table 2).

In the phytonematode analysis without incubation, it was possible to verify the presence of eggs, free-living phytonematodes (non-parasites), and the phytonematode Aphelencus sp. in all seed lots. There was no treatment effect on egg incidence, but there was a high incidence of free-living phytonematodes and Aphelencus sp. in the seeds of $\mathrm{B}$. ruziziensis and the $B$. brizantha cultivar BRS Piatã (Table 3).

After the incubation period, the incidence of eggs and freeliving phytonematodes was observed. There was no treatment effect on the incidence of eggs, and it was verified that the cultivar Xaraés presented a low incidence of freeliving phytonematodes. Furthermore, the incidence of the phytopathogenic fungi Aphelenchus sp., Aphelencoides sp., Filenchus sp., and Rotylenchulus sp. was also verified. However, there was no treatment effect on the incidence of phytopathogenic fungi for the studied species/cultivars (Table 3). No cysts were found in any of the analyzed samples.

\section{Experiment 1 vs. Experiment 2}

When analyzing the germination rate index (GRI) of the two experiments, it was observed that $B$. ruziziensis exhibited a higher GRI in both assays (Table 1). According to the calculation of the crop value obtained by both methods (based on germination and viability), it is verified, in experiment 1 , that the seed lot of $B$. ruziziensis reached the minimum standard for commercialization of $48 \%$ (Brasil, 2008; Brasil, 2010). 
In addition, the $B$. brizantha cultivar Marandu presented the lowest crop value for both methods and experiments. In both experiments, the cultivars Xaraés and Marandu grasses presented a higher frequency of dormancy. Besides, a lower germination percentage was observed after the accelerated aging of the Xaraés and Marandu seeds, in both experiments (Table 1).

In both experiments (with and without disinfection), the fungi Cladosporium sp., Rhizoctonia sp., and Fusarium sp. were predominant (Table 2). There was no treatment effect on the incidence of the fungus Rhizoctonia sp. High percentages of Fusarium sp. were verified in the seeds of all analyzed species/cultivars, both with and without disinfection and in both experiments. The exception was the cultivar Xaraés, which presented a reduction of the fungal genus Fusarium sp. when undergoing disinfection, in both experiments (Table 2).

There was no treatment effect on the incidence of Fusarium sp. in non-disinfected seeds. However, the seeds of $B$. ruziziensis showed a higher incidence of Fusarium sp. after the disinfection process, in both experiments (Table 2).

The seeds of $B$. ruziziensis exhibited higher vigor, germination, and cultural value (Table 1). However, there was also a significant presence of phytopathogens (Tables 2 and 3), conferring a high physiological quality to the seeds, but also low sanitary quality.

Furthermore, the seeds of the $B$. brizantha cultivar Marandu presented low results of vigor, germination, and crop value (Table 1), as well as high results of the incidence by fungi (Table 2) and phytonematodes (Table 3), presenting, therefore, low physiological and sanitary quality.

The seeds of the $B$. brizantha cultivar Xaraés presented low values of vigor, germination, and crop value (Table 1), as well as a low incidence of fungi and phytonematodes (Tables 2 and 3), thus possessing low physiological quality and high sanitary quality. The seeds of the B. brizantha cultivar BRS Piatã presented intermediate/average physiological and sanitary analysis results.

\section{Discussion}

The water content may be a limiting factor for the germination of non-dormant seeds, affecting the germination percentage, germination rate, and the uniformity of the process (Marcos Filho, 2015). The water content values found in experiment 1 (Table 1) are close to the values from 10.7 to $11.5 \%$ obtained by Martins and Silva (2001), to the $10.39 \%$ verified by Cardoso et al. (2014), and to the $10.5 \%$ observed by Lima et al. (2014) in studies with forage seeds. However, in experiment 2, it was verified that the seeds presented a water content below that found in the literature, being considered adequate (Table 1).

Seeds with inadequate water contents may present problems related to the limitation of germination or deterioration due to damage caused by water deficiency or excess within the seeds (Câmara and Stacciarini-Seraphin, 2002; Marcos Filho, 2015).

Regarding the first germination count, the seeds of $B$. ruziziensis and the $B$. brizantha cultivar BRS Piatã, which have a smaller size compared to the remainder, present a larger contact surface with the substrate and, consequently, might have imbibed water and germinated more rapidly (Table 1) (Marcos Filho, 2015). According to Giurizatto et al. (2003), the tegument thickness interferes with the seed germination percentage, although this parameter should not be used alone to define the physiological quality of seeds.

The seeds of $B$. ruziziensis presented a higher GRI in both experiments (Table 1), which allows inferring that a great amount of seeds has the potential for a fast and uniform establishment under field conditions (Pariz et al., 2010).

It is probable that the higher GRI observed in the seeds of $B$. ruziziensis was caused by the lower seed dormancy (Table 1) since dormancy influences the seed germination rate in an inversely proportional manner (Alves et al., 2017). It is also worth noting the greater vigor of these seeds, based on the results of the first germination count, the germination rate index, and the germination of aged seeds (Table 1).

Dormancy is characterized as the non-germination of the seed even when subjected to favorable environmental conditions and is one of the leading causes of low seed germination rates in forage species (Lacerda et al., 2010). Therefore, difficulties in handling and problems such as reduced stand, a high percentage of invasive plants, and a low supply of forage to animals may arise due to an overestimated crop value.

This phenomenon occurred more frequently in the cultivars Xaraés and Marandu (Table 1), probably due to differences in the chemical-physical constitution of their integument, hindering gas exchanges, hormonal balance, and causing embryo immaturity (Marcos Filho, 2015).

According to Câmara and Stacciarini-Seraphin (2002), the inhibition of germination in the $B$. brizantha cultivar Marandu by the seed coating possibly occurs due to a gas exchange restriction. Corroborating this argument, Meschede et al. (2004) verified that the removal of the coating in seeds of the $B$. brizantha cultivar Marandu provided better germination results, strongly indicating that the dormancy process in the cultivar has the seed coating as its primary cause.

In addition, the dormancy phenomenon may be linked to the initial vigor of seed lots. This was also valid for B. ruziziensis since it presented high vigor (first germination count, GRI, and germination of aged seeds) and low dormancy (Table 1). Regarding the germination percentage after the accelerated aging, it was observed that the cultivars Xaraés and Marandu presented low values for this variable (Table 1). This probably occurred due to protein denaturation, given the high temperature to which they were subjected during aging. Furthermore, the rapid water imbibition by the dry seeds favors the intensity of injuries, the mobilization of reserves, and the release of energy through respiration (Marcos Filho, 2015).

In the sanitary analysis of Brachiaria seeds (Table 2), corroborating the results found in this research, Mallmann et al. (2013), studying the health of grass seeds produced in the state of Mato Grosso, also reported the incidence of Cladosporium sp., Alternaria sp., and Fusarium sp. in seeds of the B. brizantha cultivar Marandu, B. syn Urochloa sp., and Panicum maximum, respectively. Furthermore, Santos et al. (2014) and Sbalcheiro et al. (2014) also reported the incidence of Aspergillus niger, Fusarium sp., Penicillium sp., and Rhizopus sp. in seeds of the B. brizantha cultivar BRS Piatã.

The fungi Cladosporium sp., Rhizoctonia sp., and Fusarium sp., which prevailed in this study (Table 2 ), can negatively impact the crop yield and consequently reduce the food supply to animals since it causes a reduction in the seed germination potential (Marchi et al., 2007; Pedroso, 2009; Marchi et al., 2010; Sbalcheiro et al., 2014). 


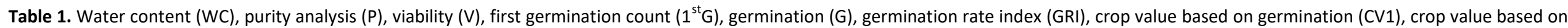

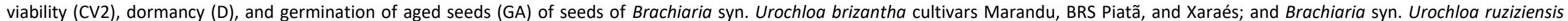
cultivar Kennedy produced in the 2017/2018 and 2018/2019 crop years, expressed as percentages (Mato Grosso, Brazil)

\begin{tabular}{|c|c|c|c|c|c|c|c|c|c|c|}
\hline Species/cultivar & WC & $\mathrm{P}$ & $\mathrm{V}$ & $1^{\text {st } G}$ & $\mathrm{G}$ & GRI & CV1 & $\mathrm{CV} 2$ & $\mathrm{D}$ & GA \\
\hline \multicolumn{11}{|l|}{ 2017/2018 } \\
\hline Xaraés & $10.60 \mathrm{a}$ & $66.06 \mathrm{~b}$ & $64.00 \mathrm{a}$ & $28.50 \mathrm{~b}$ & $49.00 \mathrm{c}$ & $35.94 \mathrm{~b}$ & $32.37 \mathrm{ab}$ & $42.28 \mathrm{a}$ & $15.00 \mathrm{a}$ & $40.50 \mathrm{~b}$ \\
\hline B. ruziziensis & $10.21 b$ & $69.43 \mathrm{~b}$ & $76.00 \mathrm{a}$ & $72.00 \mathrm{a}$ & $75.00 \mathrm{a}$ & $75.05 \mathrm{a}$ & $52.07 \mathrm{a}$ & $52.77 \mathrm{a}$ & $1.00 \mathrm{~b}$ & $76.00 \mathrm{a}$ \\
\hline BRS Piatã & $10.75 \mathrm{a}$ & $62.97 \mathrm{~b}$ & $75.50 \mathrm{a}$ & $64.00 \mathrm{a}$ & $73.50 \mathrm{~b}$ & $75.37 \mathrm{~b}$ & $46.28 \mathrm{ab}$ & $47.54 \mathrm{a}$ & $2.00 \mathrm{~b}$ & $67.50 \mathrm{a}$ \\
\hline Marandu & $10.68 \mathrm{a}$ & $75.73 \mathrm{a}$ & $33.00 \mathrm{~b}$ & $25.50 \mathrm{~b}$ & $27.50 \mathrm{~d}$ & $27.25 \mathrm{~b}$ & $20.82 \mathrm{~b}$ & $24.99 \mathrm{~b}$ & $5.50 \mathrm{ab}$ & $31.50 \mathrm{~b}$ \\
\hline \multicolumn{11}{|l|}{$2018 / 2019$} \\
\hline Xaraés & 9.03 & 97.35 a & $57.50 \mathrm{~b}$ & $2.50 \mathrm{c}$ & $24.50 \mathrm{~b}$ & $19.79 \mathrm{c}$ & $23.85 \mathrm{~b}$ & 55.98 & $33.00 \mathrm{a}$ & $7.50 \mathrm{c}$ \\
\hline B. ruziziensis & 9.85 & $93.06 \mathrm{~b}$ & $65.00 \mathrm{a}$ & $47.00 \mathrm{a}$ & $56.50 \mathrm{a}$ & $81.78 \mathrm{a}$ & $52.58 \mathrm{a}$ & 60.49 & $8.50 \mathrm{~b}$ & $46.50 \mathrm{a}$ \\
\hline BRS Piatã & 9.54 & 98.14 a & $62.00 \mathrm{a}$ & $25.50 \mathrm{~b}$ & $51.50 \mathrm{a}$ & $54.52 \mathrm{~b}$ & $50.54 \mathrm{a}$ & 60.85 & $10.50 \mathrm{~b}$ & $37.00 \mathrm{ab}$ \\
\hline Marandu & 9.91 & $92.87 \mathrm{~b}$ & $61.50 \mathrm{~b}$ & $3.00 \mathrm{c}$ & $20.5 \mathrm{~b}$ & $14.76 \mathrm{c}$ & $19.03 \mathrm{~b}$ & 57.12 & $41.00 \mathrm{a}$ & $5.50 \mathrm{bc}$ \\
\hline
\end{tabular}

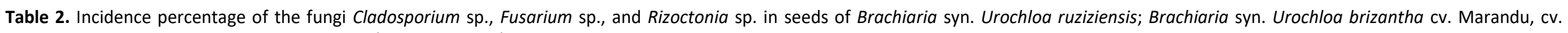
Xaraés, and cv. BRS Piatã produced in the 2017/2018 and 2018/2019 crop years (Mato Grosso, Brazil)

\begin{tabular}{|c|c|c|c|c|c|c|}
\hline Species/cultivar & $\begin{array}{l}\text { Cladospori } \\
\text { Without }{ }^{\dagger}\end{array}$ & With $\ddagger$ & $\begin{array}{l}\text { Fusarium sp. } \\
\text { Without } \dagger\end{array}$ & With $\ddagger$ & $\begin{array}{l}\text { Rizoctonia sp. } \\
\text { Without }+\end{array}$ & With $\ddagger$ \\
\hline \multicolumn{7}{|l|}{$2017 / 2018$} \\
\hline Xaraés & $2.00 \mathrm{~B}$ & 44.00 & $67.00 \mathrm{a}$ & $9.00 \mathrm{bB}$ & $18.00 \mathrm{a}$ & $0.00 \mathrm{~b}$ \\
\hline B. ruziziensis & $0.00 \mathrm{aB}$ & $5.00 \mathrm{~b}$ & 62.00 & $60.00 \mathrm{~A}$ & 3.00 & 23.00 \\
\hline BRS Piatã & $32.00 \mathrm{~A}$ & 36.00 & $88.00 \mathrm{a}$ & $53.00 \mathrm{bB}$ & 1.00 & 26.00 \\
\hline Marandu & $6.00 \mathrm{~B}$ & 14.00 & $76.00 \mathrm{a}$ & $32.00 \mathrm{bB}$ & $22.00 \mathrm{~b}$ & $25.00 \mathrm{a}$ \\
\hline \multicolumn{7}{|l|}{$2018 / 2019$} \\
\hline Xaraés & $36.00 \mathrm{~b}$ & $2.00 \mathrm{Ca}$ & $74.00 \mathrm{a}$ & $0.00 \mathrm{Bb}$ & $22.00 \mathrm{~b}$ & $3.00 \mathrm{a}$ \\
\hline B. ruziziensis & $53.00 \mathrm{~b}$ & $28.00 \mathrm{Aa}$ & $77.00 \mathrm{a}$ & $22.00 \mathrm{Ab}$ & $66.00 \mathrm{~b}$ & $11.00 \mathrm{a}$ \\
\hline BRS Piatã & $49.00 \mathrm{~b}$ & $16.00 \mathrm{ABa}$ & 63.00 & $33.00 \mathrm{~A}$ & 41.00 & 15.00 \\
\hline Marandu & $50.00 \mathrm{~b}$ & $5.00 \mathrm{BCa}$ & $87.00 \mathrm{a}$ & $28.00 \mathrm{Ab}$ & $44.00 \mathrm{~b}$ & $10.00 \mathrm{a}$ \\
\hline
\end{tabular}

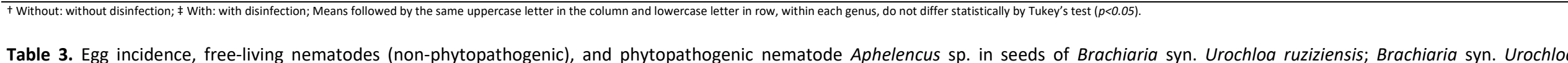
brizantha cv. Marandu, cv. Xaraés, and cv. BRS Piatã produced in the 2017/2018 and 2018/2019 crop years, expressed as unit g ${ }^{-1}$ of pure seeds (Mato Grosso, Brazil)

\begin{tabular}{|c|c|c|c|c|c|c|c|c|c|}
\hline \multirow[t]{3}{*}{ Year/ Experiment } & \multicolumn{4}{|c|}{$2017 / 2018$} & \multicolumn{5}{|c|}{$2018 / 2019$} \\
\hline & Eggs $^{\text {ns }}$ & Free-living & Eggs & Free-living & Eggs $^{\text {ns }}$ & Free-living & Aphelencus & Eggs $^{\text {ns }}$ & Free-living \\
\hline & \multicolumn{2}{|c|}{ Without incubation } & \multicolumn{2}{|c|}{ With incubation } & \multicolumn{3}{|c|}{ Without incubation } & \multicolumn{2}{|c|}{ With incubation } \\
\hline Xaraés & 148 & $68 \mathrm{~b}$ & $100 \mathrm{~b}$ & $132 \mathrm{c}$ & 0.0 & $1.20 \mathrm{c}$ & $0.00 \mathrm{~b}$ & 2.80 & $10.80 \mathrm{~b}$ \\
\hline B. ruziziensis & 156 & 468 a & $396 a$ & $489.60 \mathrm{a}$ & 0.4 & $17.40 \mathrm{a}$ & $0.40 a$ & 6.00 & $184.00 \mathrm{a}$ \\
\hline BRS Piatã & 108 & $16 \mathrm{~b}$ & $108 \mathrm{~b}$ & $208 c$ & 0.8 & $34.40 \mathrm{a}$ & $0.00 \mathrm{ab}$ & 2.40 & $147.70 \mathrm{a}$ \\
\hline Marandu & 188 & $136 \mathrm{~b}$ & 516 a & $238.80 \mathrm{~b}$ & 0.4 & $24.40 \mathrm{~b}$ & $0.40 \mathrm{~b}$ & 4.40 & $56.60 \mathrm{a}$ \\
\hline
\end{tabular}

Means followed by the same lowercase letter in the column do not differ statistically by Tukey's test $(p<0.05) \cdot$. ns: not significant $(p<0.05)$ 
Besides the physiological damage caused to the Brachiaria seeds, there are indications of the involvement of biotic agents in the mortality of the $B$. brizantha cultivar Marandu (MGM), among these, Pythium sp., Rhizoctonia sp., and Fusarium sp., especially in poorly-drained areas (Marchi et al., 2011).

Therefore, it is recommended that seed lots of the $B$. brizantha cultivar Marandu similar to the one analyzed in this study (in both experiments) should not be implanted in poorly-drained areas since they present a high incidence of Rhizoctonia sp. and Fusarium sp. (Table 2).

Furthermore, the high frequency of Fusarium sp. observed in the studied lots may be linked to the ability of the fungus in producing resistance structures with high survival rates in the soil, culminating in the existence of alternative host crops, such as cotton, Brachiaria, coffee, bean, maize, and soybean (Barros and Juliatti, 2011).

Fusarium sp. can cause seed necrosis and root rot in infected plants (Almeida, 2015); Fusarium moniliforme and Fusarium graminearum are notable for causing root and stem rot (Costa et al., 2009); Fusarium clamydosporium is known for causing wilting followed by death in forage plants, such as Stylosanthes sp. (Verzignassi and Fernandes, 2001); and Fusarium oxysporum is notable for causing wilting, yellowing, and death in Brachiaria plants (Almeida, 2015).

Based on this, it is inferred that seeds all lots in this study are unsuitable for single planting, intercropping, or crop rotation, and their adoption in integrated systems might be highly compromising.

Regarding the genus Cladosporium sp., the major barrier to the use of seeds contaminated with this fungus is that some species may cause leaf spots and lesions (Revankar and Sutton, 2010). This organism may have the ability to digest proteins in the epidermis, causing red spots or severe eruptions in animals and humans (Espinel-Ingroff et al., 1986). Therefore, the presence of this pathogen may cause problems in the implantation and conduction of the crop, and be harmful to animals and humans that have contact with contaminated pastures.

After the process of seed sanitary disinfection, in experiment 1 , it can be verified that the reduction of infestation by Fusarium sp., which is a fast-growing and aggressive fungus (Mallman et al., 2013), may have led to the growth of other fungi, such as Cladosporium sp. and Rhizoctonia sp. Furthermore, the increase in the frequency of the fungi Cladosporium sp. and Rhizoctonia sp. can be justified by their high incidence within the seed, conversely to Fusarium sp., on the seed surface (Table 2).

Conversely, in experiment 2 , an incidence reduction trend was observed for all major fungi after the disinfection process. This suggests a high fungal incidence on the seed surface, in these lots (Table 2).

In the phytonematode analysis, the eggs and phytonematodes found by the method with the incubation period may correspond to those present in the commercial sample, externally and internally transmitted to the seeds via impurities.

Mallmann et al. (2013) observed a high occurrence of Aphelenchoides sp. and Ditylenchus sp. in the cultivars Marandu and Piatã produced in the states of Mato Grosso and São Paulo. Furthermore, they found that the Panicum maximum cultivars Massai and Mombaça presented a higher incidence of Aphelenchoides sp. and Ditylenchus sp., especially in the seeds produced in Mato Grosso.
It is believed that phytonematodes may have a significant impact on dry matter production and the persistence of forage species in the field (Favoreto, 2004). In addition, there is a confirmation of the damage caused by the incidence of pathogenic phytonematodes in the implantation of integrated systems since exogenous pathogens can be inserted into agricultural areas, producing susceptible crops.

Meloidogyne sp., a phytonematode reported in this study, forms root galls, necrosis between the veins, and small and yellow plants in reeds and in soybean and maize producing areas (Freitas et al., 2001; Dias et al., 2010). Aphelencoides besseyi causes the green-stem syndrome in soybean, also attacking cotton, causing green stem and leaf retention (Dias et al., 2010; Favoreto et al., 2015; Meyer et. al., 2017). Rotylenchulus reniformis causes dwarfism, chlorosis, and leaf yellowing in the soybean and cotton crops (Embrapa Soja, 2010; 2013).

In addition to direct damage, phytonematodes constitute a significant obstacle to the exportation of forage seeds. Large importers of seeds of Brachiaria syn. Urochloa sp. and Panicum sp. impose phytosanitary restrictions on the Brazilian product (Marchi et al., 2007). Therefore, the use of seeds with low sanitary quality compromises the formation of pasture areas, commercialization of seed lots (Mallmann et al., 2013), and the large-scale adoption of sustainable crop models, such as integrated systems.

\section{Materials and Methods}

\section{Plant materials}

Seeds of Brachiaria ruziziensis and the Brachiaria brizantha cultivars Marandu, Xaraés, and BRS Piatã. The seeds were purchased within commercial packages and produced in the 2017/18 (Year 1: experiment 1) and 2018/19 crop years (Year 2: experiment 2), with the same origin (Mato Grosso, Brazil).

\section{Conduction of the study}

In year 1 (2017/18 crop year), the experiment (experiment 1 ) was conducted with seeds from the $2017 / 18$ crop year, in a randomized open design with four configurations and four replications. In year 2 (2018/19 crop year), the study was replicated (experiment 2) with the experimental conditions of the first study (randomized automatic design with four sessions and four replications), using samples from the 2018/19 crop year.

\section{Treatments}

The treatments consisted of the seeds of Brachiaria ruziziensis and the Brachiaria brizantha cultivars Marandu, Xaraés, and BRS Piatã, which are commonly used in integrated crop-livestock systems in tropical regions.

\section{Evaluated characteristics}

The following variables were evaluated in each experiment: water content, physical purity, viability (tetrazolium), first germination count, germination percentage, germination rate index (GRI), crop value based on germination, crop value based on viability, dormancy, accelerated aging, fungal incidence, and incidence of phytonematodes.

The determination of the water content was performed in three $4.0 \mathrm{~g}$ samples per treatment, which were placed in a forced-air oven for 24 hours at $105 \pm 1{ }^{\circ} \mathrm{C}$. The results were expressed as a percentage (Brasil, 2009b). 
The crop value $(\mathrm{CV})$ of the seeds was determined with purity, germination, and viability tests. The purity test was performed using two $5.0 \mathrm{~g}$ sub-samples per treatment, manually separating impurities, other seeds, and pure seeds. The portion of pure seeds was expressed as a percentage (Brasil, 2009b).

The germination test was performed with four sub-samples of 50 seeds for each treatment. The germinated seed counts were daily performed to calculate the germination rate (Maguire, 1962). The results were expressed as a percentage (Brasil, 2009b).

Seed viability was determined by the tetrazolium test with the non-germinated seeds at the end of the germination test.

The seeds immersed in tetrazolium salt were placed in a BOD incubator for 3 hours, without light, at $30{ }^{\circ} \mathrm{C}$. Afterward, the seeds were classified as either viable or nonviable. The results were expressed as a percentage (Brasil, 2009b). Seed dormancy was determined as the difference between the percentage of viable seeds and the percentage of germinated seeds.

In the accelerated aging test, the seeds of each treatment were distributed on an aluminum screen coupled to germination boxes with $40 \mathrm{~mL}$ of distilled water at the bottom (Marcos Filho, 1999). The germination test was then performed by counting the germinated seeds at seven days (Brasil, 2009b). The incidence of fungi was analyzed using a modified blotter test, both with and without previous disinfection. Disinfection was performed by soaking the seeds in a $1 \%$ sodium hypochlorite solution for 3 minutes (Brasil, 2009a). The modification of the method consisted of wetting the substrate with a previously sterilized sodium chloride $(\mathrm{NaCl})$ solution in the potential of $-0.6 \mathrm{MPa}$ (water restriction) (Machado et al., 2007).

Four sub-samples of 25 seeds were used for each treatment without the employment of previous disinfection, and another four sub-samples of 25 seeds were used for each treatment using previous disinfection (adapted from Brasil, 2009a). After seven days, the individual evaluation/examination of the seeds was performed with the aid of a magnifying glass by assessing the occurrence of typical fruiting bodies of fungal growth, with these being grouped according to the genus. The observation of slides on a light microscope was sometimes necessary in order to confirm the identity of the fungi. The results were expressed as the percentage of occurrence (Brasil, 2009a). The incidence of phytonematodes was analyzed by the extraction and wet sieving of the samples, with ten replicates of $10 \mathrm{~g}$ of commercial seeds per treatment (Coolen and D'Herde, 1972), both with and without incubation. The supernatant obtained after the procedure was poured into a 400-mesh sieve, and the retained phytonematode suspension was collected. A $1 \mathrm{~mL}$ aliquot from this suspension was analyzed with an optical microscope for the identification and quantification of the phytonematodes down to the genus level.

\section{Statistical analysis}

The data obtained on all variables, in both experiments, were transformed using the formula $v x+0.5$ and subjected to analysis of variance and Tukey's range test at $5 \%$ of probability. The computer software SANEST was used for the analyses (Zonta \& Machado, 1984).

\section{Conclusions}

Cladosporium sp., Fusarium sp., Rhizoctonia sp., Meloidogyne sp., Filenchus sp., Aphelenchus sp., Aphelencoides sp., and Rotylenchulus sp. are the main plant phytopathogens associated with the seeds of the main tropical forage species used in integrated systems.

The seeds of Brachiaria ruziziensis present high physiological quality, whereas the seeds of the Brachiaria brizantha cultivar Xaraés present high sanitary quality.

\section{Conflicts of interest}

The authors declare that no conflicts of interest.

\section{Acknowledgements}

We are grateful to UFMT, PPGAT, and CAPES.

\section{References}

Almeida MP (2015) Quality of seeds of brachiaria brizantha cv. xaraés from the field of production to storage. Federal University of Pelotas, Pelotas.

Alves BA, Medeiros LT, Sales JF, Branquinho C, Silva JW, Souza RG (2017) Germination of forage seeds of gender brachiaria a function of environments and storage times. GST. 10:11-19.

Balbino LC, Barcellos AO, Stone LF (2011) Referencial document crop-livestock-forestry integration framework. Embrapa, Brasília.

Barros FC, Juliatti FC (2012) Survey of fungi in samples received by micology and plants protect laboratory at federal university of uberlândia from 2001 to 2008. Biosci J. 8:77-86.

Brasil. Ministério da agricultura, pecuária e abastecimento (2009a) Manual of sanitary analysis of seeds. Ministry of agriculture, livestock and food supply. SNAD/ CGAL, Brasília.

Brasil. Ministério da agricultura, pecuária e abastecimento (2009b) Rules for seed analysis. Ministry of agriculture, livestock and food supply. MAPA/ACS, Brasília.

Brasil. Ministério da agricultura (2008) Normative instruction no 30 of may 21, 2008. Norms and standards for production and commercialization of seeds of tropical forage species. MAPA, Brasília.

Brasil. Ministério da agricultura (2010) Normative instruction no 30 of october 26, 2010. Amendment of normative instruction no 30 of may 21, 2008. MAPA, Brasília.

Calgaro Junior, G (2019) Dinâmica populacional de fitonematoides em sistema integrado de produção de milho. IFGO, Rio Verde.

Câmara HHLL, Stacciarini-Seraphin E (2002) Germination of seeds of brachiaria brizantha cv. marandu under different storage periods and hormonal treatment. Pesqui Agropecu Trop. 32:21-28.

Cardoso ED, De Sá ME, Haga KI, Binotti FFS, Nogueira DC, Valério Filho WV (2014) Physiological and performance in overcoming dormancy in seeds brachiaria brizantha under artificial chemical treatment and aging. Semina: Ciênc Agrár. 35:21-38.

Coolen WA, D'herde CJ (1972) A method for the quantitative extraction of nematodes from plant tissue. Nematology and Entomology Research Station, Ghent. 
Cordeiro LAM, Vilela L, Marchão RL, Kluthcouski J, Martha Junior GB (2015) Integrated crop-livestock and integrated crop-livestock-forestry systems: strategies for sustainable intensification of soil use. CC\&T. 32:15-43.

Costa RV, Casela CR, Cota LV (2009) Diseases. In: Cruz JP, Magalhães PC, Pereira Filho IA, Moreira JAA (eds) Growing maize. Embrapa, Sete Lagoas.

Dias WP, Garcia A, Silva JFV, Carneiro GES (2010) Nematodes in soybean: identification and control. Embrapa, Londrina

Embrapa Soja (2010) Soybean production technologies central Brazil 2011. Embrapa, Londrina.

Embrapa Soja (2013) Soybean production technologies central Brazil 2014. Embrapa, Londrina.

Espinel-Ingroff A, Shadomy S, Dixon D, Goldson, P (1986) Exoantigen test for cladosporium bantianum, Fonsecaea pedrosoi and phialophora verrucosa. J Clin Microbiol. 23:305-310.

Favoreto $L$ (2004) Study of nematodes in forage grass seeds. Paulista State University, Jaboticabal.

Favoreto L, Meyer MC, Klepker D, Campos LJM, Paiva EV (2015) Occurrence of aphelenchoides sp. in soybean plants with green stem symptoms. Paper presented at the Brazilian congress of nematology. Brazilian society of nematology, Londrina, 15-19 June 2015.

Freire ES, Pedroso LA, Terra WC, da Silva JCP, Marasca I, Campos VP (2018). Phytonone management in no-tillage system. New production systems.

Freitas LG, Oliveira RDL, Ferraz S (2001) Introduction to nematology. Publishing company UFV, Viçosa.

Giurizatto MIK, Souza LCF, Robaina AD, Gonçalves, MC (2003) Effects of harvest epoch and seed coat thickness on viability and vigor of soybean seeds. Cienc Agrotec. 27:771-779.

Godoy CV, Utiamada CM, Meyer MC, Campos HD, Pimenta CB, Cassetari Neto D, Venancio WS (2014) Efficiency of fungicides to control Asian soybean rust, phakopsora pachyrhizi, 2013/14 harvest: summary results of cooperative trials. Embrapa, Londrina.

Lacerda MJR, Cabral JSR, Sales JF, Freitas KR, Fontes AJ (2010) Seed dormancy-breaking of brachiaria brizantha cV. marandu. Semina: Ciênc Agrár. 31:823-828.

Lasca CC, Vechiato MH, Kohara EY (2004) Control of brachiaria spp. seed-borne fungi: effectiveness of fungicide and influence of the storage period of treated seeds on the action of these products. Arq Inst Biol. 71:465-472.

Leonel FP (2011) Crop-livestock integration: production and quality of forage. In: Zervoudakis JT, Cabral LS (eds) Nutrition and production of beef cattle. UFMT, Cuiabá.

Lima EV, Tavares JCS, Leitão-Lima PS, Pinheiro DP, Santos WM (2014) Germination and vigor of brachiaria brizantha cv. marandu seeds in function of time of mixture with urea. Braz J Agric. 89:41-52.

Macedo MCM (2009) Crop and livestock integration: the state of the art and the near future. Braz J Vet Res An Sci. 28:133-146.

Machado AQ, Machado JC, Vieira MDGGC, Cassetari Neto D, Souza MV (2007) Potential of water restriction use in cotton seed health testing. Fitopatol bras. 32:408-414.

Maguire LD (1962) Speed of germination - aid in selection and evolution for seedling emergence and vigor. Crop Sci. 2:176-177.

Mallmann G, Verzignassi JR, Fernandes CD, Santos JM, Vechiato MH, Inácio CA, Batista MV, Queiroz CA (2013) Fungi and nematodes associated with tropical forage seeds. Summa Phytopathol. 39:201-203.
Marchi CE, Fernandes CD, Bueno ML, Batista MV, Fabris LR (2010) Fungi associated to commercial seed of braquiaria grass. Arq Inst Biol. 77:65-73.

Marchi CE, Fernandes CD, Verzignassi JR (2011) Diseases in forage plants. Embrapa, Campo Grande.

Marchi CE, Fernandes CD, Borges CT, Santos JM, Jerbal VF, Trentin RA, Guimaraes LRA (2007) Phytopathogenic nematofauna of commercial seeds of tropical forages. Pesq agropec bras. 42:655-660.

Marcos Filho J (2015) Seed physiology of cultivated plants. Abrates, Londrina.

Marcos Filho J (1999) Accelerated aging test. In: Krzyzanowski FC, Vieira RD, França Neto JB (eds) Seed vigor: concepts and tests. Abrates, Londrina.

Martins L, Silva WR (2001) Dormancy performance of brachiaria brizantha seeds submitted to thermal and chemical treatments. Pesq agropec bras. 36:997-1003.

Meschede DK, Sales JGC, Braccini AL, Scapim CA, Schuab SRP (2004) Treatments to overcome brachiaria brizantha seed dormancy. J Seed Sci. 26:76-81.

Meyer MC, Favoreto L, Klepker D, Marcelino-Guimarães, FC (2017) Soybean green stem and foliar retention syndrome caused by aphelenchoides besseyi. Trop Plant Pathol. 42:403-409.

Pariz CM, Ferreira RL, Sá ME, Andreotti M, Chioderoli CA, Ribeiro AP (2010) Physiological quality of brachiaria seeds and dry mass yield estimate under different irrigated croplivestock integration systems. Pesqui Agropecu trop. 40:330-340.

Pedroso DC (2009) Association of alternaria spp. with apiaceous seeds: methods of inoculation and influence on physiological quality. Federal University of Santa Maria, Santa Maria.

Revankar SG, Sutton DA (2010). Melanized fungi in human disease. Clin Microbiol Rev. 23:884-928.

Santos GR, Tschoeke PH, Silva LG, Silveira MCAC, Reis HB, Brito DR, Carlos DS (2014) Sanity analysis, transmission and pathogenicity off fungi associated with forage plant seeds in tropical regions of Brazil. J Seed Scie. 36:54-62.

Sbalcheiro CC, Jose SCBR, Barbosa JCRCM (2014) Physiological and sanitary quality, and transmission of fungi associated with brachiaria brizantha (hochst. ex. a. rich.) Stapf seeds submitted to thermal and chemical treatments. J Seed Sci. 36:443-450.

Souza ED (2017) Technical-scientific advances and perspectives of integrated systems of agricultural production in the cerrado. 1st Brazilian congress on integrated systems of agricultural production. Cascavel, Auguste 2017.

Vechiato HM, Aparecido CC (2008) Fungi in forage grass seeds: phytosanitary restriction and detection methods. Inst Biol, São Paulo.

Verzignassi JR, Fernandes CD (2001) Forage diseases. Embrapa, Campo Grande.

Vilela L, Martha Junior GB, Macedo MCM, Marchão RL, Guimarães Júnior R, Pulrolnik K, Maciel GA (2011) Integrated crop-livestock systems in the cerrado region. Pesqui Agropecu Trop. 46:1127-1138.

Zonta EP, Machado AD (1984) Statistical analysis system for microcomputers - SANEST. Federal University of Pelotas, Pelotas. 